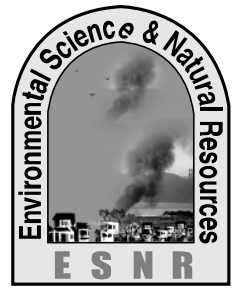

J. Environ. Sci. \& Natural Resources, 7(1): 207-213, 2014

ISSN 1999-7361

\title{
Floodwater Nitrogen, Rice Yield and N Use Efficiency as Influenced by Deep Placement of Nitrogenous Fertilizers
}

\author{
H. Afroz, M. R. Islam and M. R. Islam \\ Department of Soil Science \\ Bangladesh Agricultural University, Mymensingh-2202, Bangladesh
}

\begin{abstract}
An experiment was conducted at the Soil Science Field Laboratory of Bangladesh Agricultural University, Mymensingh during the Aus season of 2012 to investigate the effects of deep placement of nitrogen (N) fertilizers on floodwater $\mathrm{NH}_{4}-\mathrm{N}$ concentration, rice yield and $\mathrm{N}$ use efficiency under alternate wetting and drying (AWD) condition. The experiment was laid out in a randomized complete block design with three replications. There were eight treatment combinations viz. $T_{1}$ (Control), $T_{2}\left[52 \mathrm{~kg} \mathrm{~N}\right.$ from Urea super granule (USG)], $\mathrm{T}_{3}(104 \mathrm{~kg} \mathrm{~N}$ from USG), $\mathrm{T}_{4}\left[78 \mathrm{~kg} \mathrm{~N}\right.$ from prilled urea (PU)], $\mathrm{T}_{5}\left(120 \mathrm{~kg} \mathrm{~N}\right.$ from PU), $\mathrm{T}_{6}\left(51 \mathrm{~kg} \mathrm{~N}\right.$ from NPK briquette), $\mathrm{T}_{7}(78$ $\mathrm{kg} \mathrm{N}$ from USG) and $\mathrm{T}_{8}\left(78 \mathrm{~kg} \mathrm{~N}\right.$ from NPK briquette). The results regarding the floodwater $\mathrm{NH}_{4}-\mathrm{N}$ concentration revealed that, the highest value of $\left(\mathrm{NH}_{4}-\mathrm{N}\right)$ was observed at the second day of $\mathrm{PU}$ application followed by gradual decrease with time. USG and NPK briquette treated plots showed negligible amounts of $\mathrm{NH}_{4}-\mathrm{N}$ in flood water during the sampling periods. The highest grain yield $\left(5265 \mathrm{~kg} \mathrm{ha}^{-1}\right)$ and straw yield $\left(6434 \mathrm{~kg} \mathrm{ha}^{-1}\right)$ was recorded from $104 \mathrm{~kg} \mathrm{~N}$ from USG (treatment $\mathrm{T}_{3}$ ) and the lowest values were obtained from control. Apparent nitrogen recovery by rice plants was much higher when $78 \mathrm{~kg} \mathrm{~N}$ was applied as USG. Nitrogen use efficiency decreased with the increase in N rate either as PU, USG and NPK briquette and treatment $\mathrm{T}_{7}(78 \mathrm{~kg} \mathrm{~N}$ as USG) showed the highest value. These results clearly indicate that the deep placement of N in the form of USG and NPK briquette minimizes the loss of N that results in higher $\mathrm{N}$ use efficiency and increased grain yield of rice as compared to broadcast application of $\mathrm{N}$ in the form of PU.
\end{abstract}

Key Words: Deep placement of N, Flood water Ammonium, Rice yield, Nitrogen Use Efficiency

Introduction: Rice (Oryza sativa $\mathrm{L}$ ) dominates the Bangladesh agriculture sector covering $80 \%$ of the total cropped area of the country (AIS, 2008). For boosting the yield of rice, farmers are using different chemical fertilizers especially nitrogen, phosphorus and potassium. Nitrogen $(\mathrm{N})$ is the most important nutrient element for crop production. Farmers of Bangladesh use mainly urea in rice field as the most available source of nitrogen. Annual requirement of urea of the country is about 24 lakh ton of which 50\% is met by the domestic production. The rest amount of urea needs to be imported by spending a large amount of foreign currency (BBS, 2010). In rice cultivation system generally, $\mathrm{N}$ fertilizers are applied in the soil surface as conventional broadcast method. The lion part of those applied fertilizers is getting lost through a number of processes including volatilization, denitrification, run-off, leaching and fixation. These result in low crop yield and reduced efficiency of applied $\mathrm{N}$. The efficiency of applied $\mathrm{N}$ from urea fertilizer is very low (30-35 \%) in rice cultivation under continuous flooding condition (IFDC, 2007). On the contrary, alternate wetting and drying cultivation of rice can save $30 \%$ water and minimizes $\mathrm{N}$ losses to a significant extent. Loss of fertilizerderived $\mathrm{N}_{2}$ from continuous flooded soils has been found to be rather low $(<10 \%$, Nicolaisen et al., 2004). In this situation, the deep placement of $\mathrm{N}$ fertilizers (USG and NPK briquette) into the anaerobic soil zone is an effective method to reduce volatilization loss (Mikkelsen et al., 1978). Deep placement of USG at $8-10 \mathrm{~cm}$ depth of soil can save $30 \% \mathrm{~N}$ compared to PU, increases absorption rate, improves soil health and ultimately increases rice yield (Savant et al., 1991).

Again, the deep placement of USG and NPK briquette minimizes the concentration of $\mathrm{NH}_{4}-\mathrm{N}$ in floodwater compared to broadcast application of PU. Kapoor et al. (2008) reported that broadcast application of $\mathrm{N}$ as urea resulted on an average 10 times higher amounts of ammonium $\mathrm{N}$ in flood water compared to deep placement of urea briquette and NPK briquette. Islam et al. (2011) reported that application of NPK briquette $(2.4 \mathrm{~g} \mathrm{x} 2)$ produced the highest rice grain yield of $7.47 \mathrm{t} \mathrm{ha}^{-1}$ and demonstrated higher agronomic efficiency than PU and USG. They also observed that NPK briquette can save $33 \mathrm{~kg} \mathrm{~N} \mathrm{ha}^{-1}$ compared to recommend $\mathrm{PU}$. The results indicate that a great reduction in $\mathrm{NH}_{4}-\mathrm{N}$ concentration in floodwater occurs with urea deep placement (UDP). Based upon the reduced level of applied $\mathrm{N}$ required with UDP, it is apparent that there will also be a reduction in $\mathrm{N}$ losses to the atmosphere. Moreover, deep placement method of fertilizer application is environment-friendly and will not decrease the 
normal fertility of land (BRRI, 2010). However, information on deep placement of $\mathrm{N}$ in rice cultivation especially under AWD condition is scarce in Bangladesh. Therefore, the present study was undertaken to evaluate the effect of deep placement of $\mathrm{N}$ fertilizers (USG and NPK briquette) on rice yield, $\mathrm{N}$ use efficiency and floodwater $\mathrm{NH}_{4}-\mathrm{N}$ in BRRI dhan27 cultivation.

\section{Materials and Methods}

The study was carried out at the Soil Science Field laboratory of Bangladesh Agricultural University, Mymensingh during the Aus season of 2012. The soil of the experimental site belongs to the Sonatala series under the AEZ of Old Brahmaputra Floodplain. The soil was silt loam in texture having $\mathrm{pH}$ 6.07, organic matter content $1.10 \%$, total $\mathrm{N} 0.145 \%$, available $\mathrm{P} 3.8 \mathrm{ppm}$, exchangeable K $0.12 \mathrm{me} \%$ and available S 14.56 ppm. There were eight treatments with three replications. The treatments were $\mathrm{T}_{1}$ (Control), $\mathrm{T}_{2}$ (52 $\mathrm{kg} \mathrm{N}$ from USG), $\mathrm{T}_{3}\left(104 \mathrm{~kg} \mathrm{~N}\right.$ from USG), $\mathrm{T}_{4}(78$ $\mathrm{kg} \mathrm{N}$ from PU), $\mathrm{T}_{5}(120 \mathrm{~kg} \mathrm{~N}$ from $\mathrm{PU}), \mathrm{T}_{6}(51 \mathrm{~kg} \mathrm{~N}$ from NPK briquette), $\mathrm{T}_{7}$ (78 $\mathrm{kg} \mathrm{N}$ from USG), $\mathrm{T}_{8}(78$ $\mathrm{kg} \mathrm{N}$ from NPK briquette). The experiment was laid out in a randomized block design. BRRI dhan 27 was used as the test crop. Thirty-day old seedlings of BRRI dhan27 were transplanted in the experimental plots maintaining a spacing of $20 \mathrm{~cm}$ x $20 \mathrm{~cm}$. Three seedlings were transplanted in each hill. Intercultural operations such as irrigation, weeding etc. were done as and when required. For maintaining AWD condition a PVC pipe was used and irrigations were applied when water level goes below $15 \mathrm{~cm}$ from the soil surface.

The fertilizers were applied as per treatments. All the treatments except $\mathrm{T}_{6}$ and $\mathrm{T}_{7}$ received $16 \mathrm{~kg} \mathrm{P}$ and 42 $\mathrm{kg} \mathrm{K} \mathrm{ha}{ }^{-1}$ from TSP and MoP, respectively. Prilled urea was applied in three equal splits. The first split was applied after 7 days of transplanting. The second and third splits of PU were applied after 30 and 45 days of transplanting. Before application of $\mathrm{N}$ fertilizers, the water in the rice plots was drained out. PU was applied to the fields and mixed with the soils. The USG and NPK briquettes were placed at $8-10 \mathrm{~cm}$ depth between four hills at alternate rows after 7 days of transplanting.

Water samples were collected for three different times from BRRI dhan 27 rice field. First sampling was done immediately after the application of USG, NPK briquettes and PU. The second and third samplings were done after each split application of PU. For every sampling, water samples were collected for seven consecutive days. The collected water samples were brought to the laboratory for determining $\mathrm{NH}_{4}-\mathrm{N}$ concentration. The concentration of $\mathrm{NH}_{4}-\mathrm{N}$ was determined by Phenol-hypochlorite method (Solorzano, 1969).

The crop was harvested at full maturity and the grain and straw yields were recorded. The grain yield was expressed on $14 \%$ moisture basis and the straw yield on sun dry basis. The grain and straw samples were analyzed for $\mathrm{N}$ content following semimicro Kjeldahl method (Bremner and Mulvaney, 1982). The $\mathrm{N}$ uptake by grain and straw was determined from $\mathrm{N}$ content and yield data. The $\mathrm{N}$ use efficiency ( $\mathrm{kg}$ grain yield increase $\mathrm{kg}^{-1} \mathrm{~N}$ applied) and apparent $\mathrm{N}$ recovery were determined by the following formulae: $\mathrm{NUE}=\left(\mathrm{Gy}_{+\mathrm{N}}-\mathrm{Gy}_{\mathrm{ON}}\right) / \mathrm{FN}$, where $\mathrm{Gy}_{+\mathrm{N}}=$ grain yield in treatment with $\mathrm{N}$ application; $\mathrm{Gy}_{\mathrm{ON}}=$ grain yield in treatment without $\mathrm{N}$ application and $\mathrm{FN}=$ amount of fertilizer $\mathrm{N}$ applied $\left(\mathrm{kg} \mathrm{ha}^{-1}\right)$ and ANR $\left(\mathrm{kg} \mathrm{ha}^{-1}\right)=\left(\mathrm{UN}_{+\mathrm{N}}-\mathrm{UN}_{0 \mathrm{~N}}\right) / \mathrm{FN}$ Where, $\mathrm{UN}_{+\mathrm{N}}$ is total $\mathrm{N}$ uptake $\left(\mathrm{kg} \mathrm{ha}^{-1}\right)$ with grain and straw; $\mathrm{UN}_{0 \mathrm{~N}}$ is the $\mathrm{N}$ uptake $\left(\mathrm{kg} \mathrm{ha}^{-1}\right)$ in control; $\mathrm{FN}$ is amount of fertilizer $\mathrm{N}$ applied $\left(\mathrm{kg} \mathrm{ha}^{-1}\right)$. All the data were statistically analyzed by F-test and the mean differences were ranked by DMRT at $5 \%$ level (Gomez and Gomez, 1984).

\section{Results and Discussion}

\section{$\mathrm{NH}_{4}-\mathrm{N}$ concentration in rice field water}

The results on the $\mathrm{NH}_{4}-\mathrm{N}$ concentration in floodwater as influenced by different treatments have been reported in Figure 1. In all three samplings, the amount of available $\mathrm{NH}_{4}-\mathrm{N}$ in rice field water released from PU $\left(\mathrm{T}_{4}\right.$ and $\left.\mathrm{T}_{5}\right)$ started to increase after application of PU, continued up to 2-3 days and then decreased gradually up to 7 days (Figure 1). In USG and NPK briquette plots, the $\mathrm{NH}_{4}-\mathrm{N}$ in surface water did not show any significant variation among the treatments including $\mathrm{T}_{2}, \mathrm{~T}_{3}, \mathrm{~T}_{6}, \mathrm{~T}_{7}$ and $\mathrm{T}_{8}$ although the values of $\mathrm{NH}_{4}-\mathrm{N}$ in first sampling were a bit higher than that in second and third samplings as USG and NPK briquette were not applied in the preceding samplings. However, a continuous release of $\mathrm{NH}_{4}-\mathrm{N}$ in the rice field water was observed during the sampling period in case of deep placement of USG and NPK briquette. In first sampling, the treatment with 120 $\mathrm{kg} \mathrm{N}$ from $\mathrm{PU}\left(\mathrm{T}_{5}\right)$ showed higher $\mathrm{NH}_{4}-\mathrm{N}$ concentration than those with $78 \mathrm{~kg} \mathrm{~N}$ from urea $\left(\mathrm{T}_{4}\right)$. In both the treatments $\left(\mathrm{T}_{4}\right.$ and $\left.\mathrm{T}_{5}\right)$, the highest concentration of $\mathrm{NH}_{4}$ $\mathrm{N}$ was observed at day 2 and then decreased with time. By day 6 the concentration of $\mathrm{NH}_{4}-\mathrm{N}$ in all treatments became almost similar. The USG treated plots $\left(\mathrm{T}_{2}, \mathrm{~T}_{3}\right.$ and $\mathrm{T}_{7}$ ) and NPK briquette treated plots $\left(\mathrm{T}_{6}\right.$ and $\left.\mathrm{T}_{8}\right)$ had much lower concentration of $\mathrm{NH}_{4}-\mathrm{N}$ in floodwater indicating that deep placement of urea fertilizer can reduce $\mathrm{N}$ loss 
by $\mathrm{NH}_{3}$ volatilization. Deep placement of $\mathrm{N}$ reduces $\mathrm{NH}_{4}-\mathrm{N}$ in water. This not only improves fertilizer $\mathrm{N}$ use efficiency of rice but also minimizes $\mathrm{N}$ loss resulting from ammonia volatilization and denitrification (Savent and Stangel, 1990; Mohanty et al. 1999). Xiang et al. (2013) also found lower $\mathrm{NH}_{4}-\mathrm{N}$ in floodwater in deep placed fertilizer treated plots compared to traditional broadcast application of PU.

In case of second and third sampling, the amount of available $\mathrm{NH}_{4}-\mathrm{N}$ in flood water of BRRI dhan 27 rice field followed the similar trend as that of first sampling.
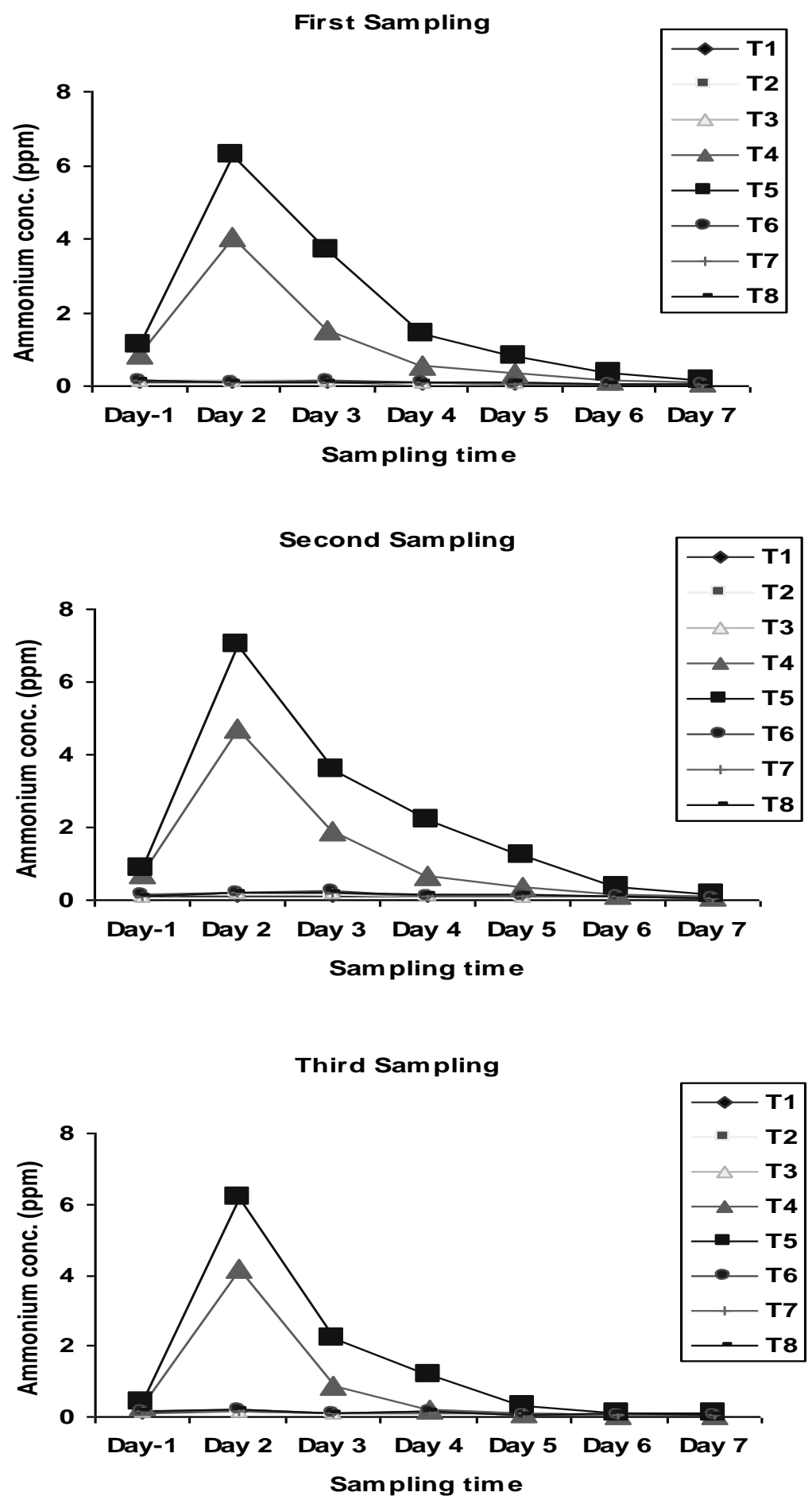

Fig 1: Ammonium concentration in floodwater after application of $\mathrm{N}$ fertilizers 


\section{Grain yield}

The grain yield of BRRI dhan27 ranged from $3133 \mathrm{~kg} \mathrm{ha}^{-1}$ to $5265 \mathrm{~kg} \mathrm{ha}^{-1}$ due to different treatments (Table 1). The highest grain yield of $5265 \mathrm{~kg} \mathrm{ha}^{-1}$ was obtained in $\mathrm{T}_{3}$ treatment (104 kg N from USG) followed by $\mathrm{T}_{7}(78 \mathrm{~kg}$ $\mathrm{N}$ from USG) and $\mathrm{T} 8$ (78 Kg N from NPK briquette). The grain yields obtained in treatments with $52 \mathrm{~kg} \mathrm{~N}$ from USG and $120 \mathrm{~kg} \mathrm{~N}$ from PU were statistically similar. Again, in treatments with $78 \mathrm{~kg} \mathrm{~N}$ from PU and $51 \mathrm{~kg} \mathrm{~N}$ from NPK briquette produced statistically similar grain yield. The lowest grain yield of $3133 \mathrm{~kg} \mathrm{ha}^{-1}$ was observed in $\mathrm{T}_{1}$ (control). The increase in grain yield over control ranged form 32.60 to $68.04 \%$ where the highest increase was obtained in $\mathrm{T}_{3}$ and the lowest one was obtained with $\mathrm{T}_{4}$ (Table 1). USG followed by NPK briquettes performed better in increasing grain yield of rice compared to PU. The increase in rice yield as observed in the present study is due to the spontaneous supply of nitrogen from USG and NPK briquettes throughout the growing period of rice and due to minimum loss of nitrogen as because of deep placement. These findings are well supported with Kapoor et al. (2008); Islam et al. (2011) and Naznin et al. (2013) who observed increased rice yield due to application of USG and NPK briquettes.

\section{Straw yield}

Straw yield of BRRI dhan27 also responded significantly to different treatments under study. The yields of straw ranged from 3944 to $6434 \mathrm{~kg} \mathrm{ha}^{-1}$ (Table 1). The highest straw yield of $6434 \mathrm{~kg} \mathrm{ha}^{-1}$ was obtained in $\mathrm{T}_{3}$ (104 kg N from USG) which was identical with that of treatment $\mathrm{T}_{7}(78 \mathrm{~kg} \mathrm{~N}$ from USG). The straw yield produced by treatments with $52 \mathrm{~kg} \mathrm{~N}$ from USG, $78 \mathrm{~kg} \mathrm{~N}$ from PU and $51 \mathrm{~kg} \mathrm{~N}$ from NPK briquette were statistically similar. Regarding the percent increase of straw yield, maximum increase $(63.14 \%)$ was noted in $\mathrm{T}_{3}$ and the minimum one $(20.98 \%)$ was found in $\mathrm{T}_{6}$ as shown in Table 1.

Table 1. Effect of deep placement of $\mathrm{N}$ fertilizers on the yield of BRRI dhan27

\begin{tabular}{|l|c|c|c|c|}
\hline \multicolumn{1}{|c|}{ Treatments } & $\begin{array}{c}\text { Grain yield } \\
\left(\mathbf{k g ~ h a}^{-1}\right)\end{array}$ & $\begin{array}{c}\text { \% increase over } \\
\text { control }\end{array}$ & $\begin{array}{c}\text { Straw yield } \\
\left(\mathbf{k g ~ h a}^{-1}\right)\end{array}$ & $\begin{array}{c}\text { \% increase over } \\
\text { control }\end{array}$ \\
\hline $\mathrm{T}_{1}(\mathrm{Control})$ & $3133 \mathrm{f}$ & - & $3944 \mathrm{e}$ & - \\
\hline $\mathrm{T}_{2}(52 \mathrm{~kg} \mathrm{~N}$ from USG) & $4453 \mathrm{~d}$ & 42.14 & $5121 \mathrm{~d}$ & 29.83 \\
\hline $\mathrm{T}_{3}(104 \mathrm{~kg}$ N from USG) & $5265 \mathrm{a}$ & 68.04 & $6434 \mathrm{a}$ & 63.14 \\
\hline $\mathrm{T}_{4}(78 \mathrm{~kg} \mathrm{~N}$ from PU) & $4154 \mathrm{e}$ & 32.60 & $4906 \mathrm{~d}$ & 24.40 \\
\hline $\mathrm{T}_{5}(120 \mathrm{~kg}$ N from PU) & $4431 \mathrm{~d}$ & 41.43 & $5574 \mathrm{c}$ & 41.34 \\
\hline $\mathrm{T}_{6}(51 \mathrm{~kg}$ N from NPK briquette $)$ & $4228 \mathrm{e}$ & 34.94 & $4771 \mathrm{~d}$ & 20.98 \\
\hline $\mathrm{T}_{7}(78 \mathrm{~kg}$ N from USG) & $5154 \mathrm{~b}$ & 64.49 & $6284 \mathrm{ab}$ & 59.33 \\
\hline $\mathrm{T}_{8}(78 \mathrm{~kg}$ N from NPK briquette $)$ & $4870 \mathrm{c}$ & 55.44 & $5933 \mathrm{bc}$ & 50.44 \\
\hline $\mathrm{CV}(\%)$ & 1.06 & - & 4.16 & - \\
\hline $\mathrm{SE}( \pm)$ & 27.31 & - & 129 & - \\
\hline
\end{tabular}

The figure(s) in a column do not differ significantly at 5\% level of probability

$\mathrm{CV}=\mathrm{Co}-$ efficient of variation and $\mathrm{SE}=$ Standard error of means

\section{Nitrogen content}

The $\mathrm{N}$ content in grain and straw of BRRI dhan 27 was influenced significantly by the application of PU, USG and NPK briquettes (Table 2). The highest $\mathrm{N}$ content of $1.21 \%$ was observed in $\mathrm{T}_{3}(104 \mathrm{~kg} \mathrm{~N}$ from USG) which was statistically similar with that of treatment $\mathrm{T}_{7}\left(78 \mathrm{~kg} \mathrm{~N}\right.$ from USG) and $\mathrm{T}_{8}(78 \mathrm{~kg} \mathrm{~N}$ from NPK briquette) with the value of 1.19 and $1.15 \%$. The lowest $\mathrm{N}$ content of $0.91 \%$ was noted in $\mathrm{T}_{1}$ (Control). The $\mathrm{N}$ content in the straw ranged from $0.52 \%$ in $\mathrm{T}_{1}$ to 0.71 in $\mathrm{T}_{3}$. The results revealed that $\mathrm{N}$ content in rice grain was higher than that of straw.

\section{Nitrogen uptake}

The $\mathrm{N}$ uptake both by grain and straw of BRRI dhan27 varied significantly due to deep placement of USG and NPK briquettes. The $\mathrm{N}$ uptake by grain ranged from 28.47 to $63.83 \mathrm{~kg} \mathrm{ha}^{-1}$ and that by straw from 20.48 to $45.64 \mathrm{~kg} \mathrm{ha}^{-1}$. The highest $\mathrm{N}$ uptake by grain $\left(63.83 \mathrm{~kg} \mathrm{ha}^{-1}\right)$ and by straw $\left(45.64 \mathrm{~kg} \mathrm{ha}^{-1}\right)$ was recorded in $\mathrm{T}_{3}$ (104 $\mathrm{kg} \mathrm{N}$ from USG) which was identical with treatment $\mathrm{T}_{7}$ (78 kg N from USG) and the lowest $\mathrm{N}$ uptake by grain $\left(28.47 \mathrm{~kg} \mathrm{ha}^{-1}\right)$ and by straw (20.48 kg ha ${ }^{-1}$ ) was found in $\mathrm{T}_{1}$ (Table 2). The highest total $\mathrm{N}$ uptake $\left(109.5 \mathrm{Kg} \mathrm{ha}^{-1}\right)$ was observed in $\mathrm{T}_{3}$ and the lowest value (48.95 $\mathrm{Kg} \mathrm{ha}^{-1}$ ) was found in $\mathrm{T}_{1}$. Jahan et al. (2014) observed increased $\mathrm{N}$ uptake by the deep placement of USG. 
Table 2. N content and uptake of BRRI dhan27 as influenced by deep placement of $\mathrm{N}$ fertilizers

\begin{tabular}{|c|c|c|c|c|c|}
\hline \multirow[t]{2}{*}{ Treatments } & \multicolumn{2}{|c|}{$\mathrm{N}$ content $(\%)$} & \multicolumn{3}{|c|}{$\mathrm{N}$ uptake $\left(\mathrm{kg} \mathrm{ha}^{-1}\right)$} \\
\hline & Grain & Straw & Grain & Straw & Total \\
\hline $\mathrm{T}_{1}$ (Control) & $0.91 \mathrm{e}$ & $0.52 \mathrm{~h}$ & $28.47 \mathrm{f}$ & $20.48 \mathrm{e}$ & $48.95 \mathrm{e}$ \\
\hline $\mathrm{T}_{2}(52 \mathrm{~kg} \mathrm{~N}$ from USG) & $1.08 \mathrm{~cd}$ & $0.67 \mathrm{c}$ & $48.04 \mathrm{~cd}$ & $34.43 \mathrm{c}$ & $82.47 \mathrm{c}$ \\
\hline $\mathrm{T}_{3}(104 \mathrm{~kg} \mathrm{~N}$ from USG) & $1.21 \mathrm{a}$ & $0.71 \mathrm{a}$ & $63.83 a$ & $45.64 a$ & $109.5 \mathrm{a}$ \\
\hline $\mathrm{T}_{4}(78 \mathrm{~kg} \mathrm{~N}$ from $\mathrm{PU})$ & $1.05 \mathrm{~cd}$ & $0.56 \mathrm{~g}$ & $43.58 \mathrm{de}$ & $27.42 \mathrm{~d}$ & $71.0 \mathrm{~d}$ \\
\hline $\mathrm{T}_{5}(120 \mathrm{~kg} \mathrm{~N}$ from $\mathrm{PU})$ & $1.10 \mathrm{bcd}$ & $0.614 \mathrm{e}$ & $48.81 \mathrm{c}$ & $34.25 \mathrm{c}$ & $83.07 \mathrm{c}$ \\
\hline $\mathrm{T}_{6}(51 \mathrm{~kg} \mathrm{~N}$ from NPK briquette $)$ & $1.008 \mathrm{~d}$ & $0.57 f$ & $42.61 \mathrm{e}$ & $27.33 d$ & $69.95 \mathrm{~d}$ \\
\hline $\mathrm{T}_{7}(78 \mathrm{~kg} \mathrm{~N}$ from USG) & $1.19 \mathrm{ab}$ & $0.69 b$ & $61.36 a$ & $43.56 a$ & $105.0 \mathrm{a}$ \\
\hline $\mathrm{T}_{8}(78 \mathrm{~kg} \mathrm{~N}$ from NPK briquette & $1.15 \mathrm{abc}$ & $0.63 \mathrm{~d}$ & $56.01 \mathrm{~b}$ & $37.61 \mathrm{~b}$ & $93.61 b$ \\
\hline $\mathrm{CV}(\%)$ & 5.14 & 1.92 & 5.34 & 4.18 & 3.75 \\
\hline SE (\%) & 0.03 & 0.01 & 1.51 & 0.82 & 1.79 \\
\hline
\end{tabular}

The figure(s) in a column do not differ significantly at 5\% level of probability

$\mathrm{CV}=\mathrm{Co}-$ efficient of variation and $\mathrm{SE}=$ Standard error of means

\section{Nitrogen Use Efficiency (NUE)}

Nitrogen use efficiency represents the response of rice plant in terms of grain yield to $\mathrm{N}$ fertilizer. The NUE of BRRI dhan27 varied from 10.82 to $25.90 \mathrm{~kg}$ grain per $\mathrm{kg} \mathrm{N}$ applied (Figure 2). The highest value of NUE (25.90 kg grain increase per $\mathrm{kg} \mathrm{N}$ applied) was obtained in $\mathrm{T}_{7}\left(78 \mathrm{~kg} \mathrm{~N}\right.$ from USG) followed by $\mathrm{T}_{2}$ (52 kg $\mathrm{N}$ from USG), $\mathrm{T}_{8}(78 \mathrm{~kg} \mathrm{~N}$ from NPK briquette) with the value of 25.39 and $22.27 \mathrm{~kg}$ grain increase per $\mathrm{kg} \mathrm{N}$ applied. The lowest value $(10.82 \mathrm{~kg}$ grain increase per $\mathrm{kg} \mathrm{N}$ applied) was found in $\mathrm{T}_{5}$ (120 $\mathrm{kg} \mathrm{N}$ from PU). Deep placement of USG increased nitrogen use efficiency by keeping most of the urea nitrogen in the soil, close to plant roots and out of the irrigation water. Naznin et al. (2013) also observed increased $\mathrm{N}$ use efficiency due to deep placement of USG and NPK briquettes.

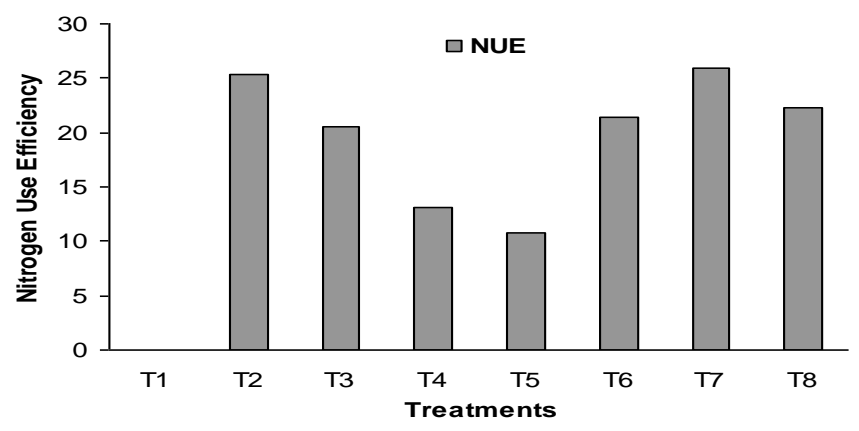

Fig 2: Nitrogen use efficiency as influenced by deep placement of $\mathrm{N}$ fertilizers

\section{Apparent N Recovery (ANR)}

The apparent $\mathrm{N}$ recovery by BRRI dhan 28 rice is presented in Figure 3. Mean apparent recovery of $\mathrm{N}$ by rice ranged from 28.27 to $71.76 \%$ in different treatments. The maximum value of apparent $\mathrm{N}$ recovery was obtained with the application of $78 \mathrm{~kg} \mathrm{~N}$ from USG in treatment $\mathrm{T}_{7}$ followed by $\mathrm{T}_{2}(52 \mathrm{~kg} \mathrm{~N}$ from USG), $\mathrm{T}_{3}\left(52 \mathrm{~kg} \mathrm{~N}\right.$ from USG), $\mathrm{T}_{8}(78 \mathrm{~kg} \mathrm{~N}$ from NPK briquette) and the minimum value was found in $\mathrm{T}_{4}(78 \mathrm{~kg} \mathrm{~N}$ from $\mathrm{PU})$. The data clearly indicate that the deep placement of USG and NPK briquettes enhanced the recovery of applied $\mathrm{N}$ 
compared to broadcast application of PU. The reasons for high recovery of applied $\mathrm{N}$ could be the deep placement of USG in rice field that resulted in continuous supply of available nitrogen throughout the growth period of rice plant, which ultimately gave maximum $\mathrm{N}$ uptake.

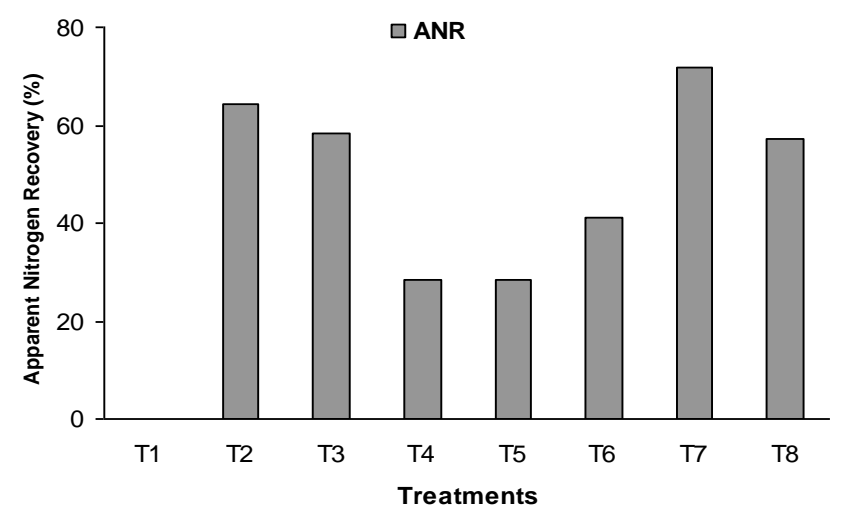

Fig 3: Influence of deep placement of $\mathrm{N}$ fertilizers on apparent $\mathrm{N}$ recovery

\section{Conclusion}

The overall results clearly indicate that the maximum values of grain and straw yields, total $\mathrm{N}$ uptake, apparent $\mathrm{N}$ recovery and $\mathrm{N}$ use efficiency were obtained with the deep placement of $\mathrm{N}$ fertilizers (USG and NPK briquette) compared to PU. The deep placement of USG and NPK briquettes enhanced the recovery of applied $\mathrm{N}$ and $\mathrm{N}$ use efficiency in comparison with broadcast application of PU. As a consequence, the grain yield of BRRI dhan28 was increased to a significant extent. Based on overall results, it can be concluded that deep placement on $\mathrm{N}$ fertilizers under AWD condition can be practised for rice cultivation for getting increased yield, and $\mathrm{N}$ use efficiency and for reducing $\mathrm{N}$ losses.

\section{Acknowledgements}

This research work was partially supported by Green House Gas Emission project (BAU component) funded by USAID-IFDC.

\section{References}

AIS (Agriculture Information Service). 2008. Krishi Diary, AIS, Ministry of Agriculture, Govt. People's Repub. Bangladesh.

BBS (Bangladesh Bureau of Statistics) 2010: Statistical Year Book of Bangladesh. Bangladesh Bur. Stat. Div. Minis. Plan. Govt. People's Repub. Bangladesh.

Bremner, J.M. and Mulvaney, C.S. 1982: Nitrogentotal, In Methods of Soil Analysis Part 2, Page, A.L.; Miller, R.H. and Keeney, D.R. (Editors): American Society of Agronomy,
Inc, Publisher, Madison, Wisconsin USA. pp. 595-624.

BRRI. 2010. Annual Report of Soil and Fertilizer Management Programme. Bangladesh Rice Research Institute, Joydebpur, Gazipur. pp. 15-20.

Gomez, K.A. and Gomez, A.A. 1984. Statistical Procedures for Agricultural Research. $2^{\text {nd }}$ Ed., John Wiley and Sons, New York. pp. 97-111.

IFDC (International Fertilizer Development Centre) 2007: Mitigating poverty and environmental degradation through nutrient management in South Asia. IFDC Report, March 2007.

Islam, M.S.; Rahman, F. and Hossain, A.T.M.S. 2011. Effects of NPK Briquette on Rice (Oryza sativa) in tidal flooded ecosystem. The Agriculturists, 9(1\&2) 37-43.

Jahan, N.; Islam, M. R.; Siddique, A. B.; Islam, M.R.; Hasan, M. M.; Shamsuzzaman, S. M. and Samsuri, A. W. 2014. Effects of integrated use of prilled urea, urea super granule and poultry manure on yield of transplant aus rice and field water quality. Life Science Journal, 11(8): 101-108.

Kapoor, V.; Singh, U.; Patil, S. K.; Magre, H.; Shrivastava, L. K.; Mishra, V. N.; Das, R. O.; Samadhiya, V. K.; Sanabria J. and Diamond. R. 2008. Rice growth, grain yield, and floodwater nutrient dynamics as affected 
by nutrient placement method and rate. Agronomy Journal, 100: 526-536.

Mikkelsen, M.R.; Datta, D. and Obcemea, W.N. 1978. Ammonia volatilization from flooded rice soils. Journal of American Society of Soil Science, 42: 725-730

Mohanty, S.K.; Singh, U.; Balasubramanian, V. and Jha, K.P. 1999. Nitrogen deep placement technologies for productivity, profitability and environmental quality of rainfed low land rice systems. Nutrient Cycling in Agroecosystem, 53(1) 43-57.

Naznin, A.; Afroz, H.; Hoque, T.S. and Mian, M.H. 2013. Effects of PU, USG and NPK Briquette on nitrogen use efficiency and yield of BR22 rice under reduced water condition. Journal of the Bangladesh Agricultural University, 11(2): 215-220.

Nicolaisen, M.H.; Risgaard-Petersen, N.; Revsbech, N.P.; Reichardt,W. and Ramsing, N.B. 2004. Nitrification-denitrification dynamics and community structure of $\mathrm{NH}_{3}$-oxidizing bacteria in a high yield irrigated Philippine rice field. FEMS Microbiology Ecology, 49: 359-369.

Savant, N.K. and Stangel, P.J. 1990. Deep placement of urea super granule in transplanted rice: principles and practices. Fertilizer Research, 25: $1-83$.

Savant, N.K.; Crasewer, E.T. and Diamond, R.B. 1991. Use of urea super granules for wetland rice: a review. Fertilizer News, 18(8): 27-35.

Solorzano L. 1969. Determination of Ammonia in Natural Waters by the Phenolhypochloride Method. Limnology and Oceanography 14: 799-801.

Xiang, J.; Haden, V.R.; Bouman, A.M. and Zhu, D. 2013. Effect of deep placement of nitrogen fertilizer on growth, yield and nitrogen uptake of aerobic rice. Australian Journal of Crop Science, 7(6): 870-877. 